\title{
Penambahan Fitur Laporan Pengerjaan Sholat Dan Hapalan Al-Qur'an Pada Aplikasi Media Komunikasi Siswa SDIT
}

\author{
Desi Windi Sari ${ }^{1}$, Abdul Haris Dalimunthe ${ }^{2}$, Melia Sari ${ }^{3}$ \\ 1,2,3 Fakultas Teknik, Jurusan Teknik Elektro, Univeristas Sriwijaya, Palembang, Indonesia \\ Email: 1, ${ }^{*}$ desi_windi@unsri.ac.id, ${ }^{2}$ harisdalimunthe@ft.unsri.ac.id, ${ }^{3}$ meliasari@ft.unsri.ac.id ${ }^{3}$
}

\begin{abstract}
Abstrak-Penelitian perancangan aplikasi mobile sebagai media komunikasi dan penyebaran informasi untuk sekolah dasar berbasis Android telah ada pada tahun 2019. Penelitian tersebut menghasilkan aplikasi mobile yang dapat diimplementasikan di sekolah dasar. Namun khusus pada Sekolah Dasar Islam Terpadu (SDIT) terdapat suatu kegiatan yang mewajibkan para siswa untuk melaporkan pengerjaan sholat sehari-hari melalui pemantauan guru beserta orang tua dan juga hapalan Al-Qur'an terutama surat pendek sebagai syarat kelulusan. Penambahan fitur laporan pengerjaan sholat dan hapalan Al-Qur'an siswa pada aplikasi mobile tersebut sangatlah membantu dan bermanfaat untuk SDIT. Fitur tersebut diharapkan kepada guru beserta orang tua dapat membimbing dan memantau siswa dalam kegiatan menjalankan sholat sehari-hari dan menghapal Al-Qur'an guna pembentukan karakter religius. Aplikasi mobile ini berbasis Android dan dirancang dengan menggunakan pendekatan Agile Extreme Programming (XP). Aplikasi pengembangan dengan memanfaatkan software Ionic, Personal Home Page (PHP), data base MySQL, serta pengujian sistem mengunakan metode pengujian black box. Hasil pengujian menunjukan bahwa aplikasi berjalan dengan lancar sesuai dengan fungsinya.
\end{abstract}

Kata Kunci: Aplikasi Mobile, SDIT, Laporan pengerjaan sholat, Hapalan Al-Qur'an

Abstract-Research on the design of mobile applications as a medium of communication and information dissemination for Android-based elementary schools has existed in 2019. This research produces a mobile application that can be implemented in elementary schools. However, specifically in the Integrated Islamic Primary School (SDIT), there is an activity that requires students to report daily prayer work through teachers and parents and also memorizing the Al-Qur'an, especially short letters as a requirement for graduation. The addition of the features of the report on the work of students' prayer and memorization of the Al-Qur'an on the mobile application is very helpful and useful for SDIT. This feature is expected that teachers and parents can guide and monitor students in carrying out their daily prayers and memorizing the Al-Quran in order to build religious character. This mobile application is based on Android and is designed using the Agile Extreme Programming (XP) methodology. Application development using Ionic software, Personal Home Page (PHP), MySQL database, and testing system using black box testing method. The test results show that the application runs smoothly according to its function.

Keywords: Mobile Application, SDIT, Prayer Report, Al - Quran Memorization.

\section{PENDAHULUAN}

Penelitian perancangan aplikasi mobile sebagai media komunikasi dan penyebaran informasi untuk sekolah dasar berbasis Android telah dilakukan pada tahun 2019. Penelitian tersebut menghasilkan sistem berupa aplikasi mobile yang dapat diimplementasikan di sekolah dasar. Perancangan aplikasi tersebut bertujuan menciptakan aplikasi mobile yang dapat digunakan oleh para orang tua siswa, guru, dan sekolah sebagai media komunikasi dan bertukar informasi guna menunjang kegiatan sekolah para anak didik [1].

Khusus pada Sekolah Dasar Islam Terpada (SDIT) ada kegiatan siswa diwajibkan untuk melaporkan pengerjaan sholat sehari-hari melalui pemantauan orang tua dan juga hapalan Al-Qur'an terutama surat pada AlQur'an sebagai syarat kelulusan. Sehingga penambahan fitur laporan pengerjaan sholat dan hapalan al-qur'an siswa pada aplikasi mobile tersebut sangatlah membantu dan bermanfaat untuk SDIT. Fitur tersebut diharapkan kepada guru dan orang tua dapat membimbing dan memantau siswa dalam kegiatan menjalankan sholat seharihari dan menghapal Al-Qur'an guna pembentukan karakter religius.

Sangatlah bermanfaat dilakukan suatu penelitian guna menambah fitur yang berfungsi sebagai sistem laporan kegiatan sholat sehari-hari dan hapalan Al-Qur'an para siswa pada aplikasi mobile sebagai media komunikasi dan penyebaran informasi untuk sekolah dasar yang telah diciptakan pada penelitian sebelumnya. Kedepannya aplikasi dengan fitur tambahan tersebut akan sangan bermanfaat bagi kegiatan di SDIT. Maka penelitian lanjutan diberi judul "Penambahan Fitur Laporan Pengerjaan Sholat Dan Hapalan Al-Qur'an Siswa Pada Aplikasi Mobile Media Komunikasi Untuk Sekolah Dasar Islam Terpadu". Aplikasi mobile tersebut dirancang dengan menggunakan metode yang mengacu pada metodologi Agile Extreme Programming (XP) dimana proses pengembangan sistem membutuhkan waktu yang relatif cepat dan tidak membutuhkan resources yang besar [2].

Beberapa software yang digunakan pada pengembangan aplikasi ini adalah Ionic, CodeIgniter, Netbean IDE, Visual Studio Code, dan UML 2.0. Ionic bersifat hybrid yang hanya 1 kali koding sehingga aplikasi dapat dibuild untuk beragam perangkat maka kelebihan berupa mempersingkat waktu dalam pengembangan [3]. 
Codeigniter sebagai framework PHP menghasilkan struktur pemrograman yang sangat rapi, baik dari segi kode maupun struktur file [4][5]. Netbean IDE dan Visual Studio Code media editor yang dapat berjalan pada berbagai macam platform / sistem operasi komputer dan sangat mendukung proses pengembangan sistem [6]. UML 2.0 merupakan tools yang menyediakan bahasa pemodelan visual sehingga memudahkan pada tahap desain sistem[7].

\section{METODE PENELITIAN}

Metode penelitian ini menggunakan pendekatan perancangan perangkat lunak Agile Extreme Programming (XP) agar proses pengembangan menjadi lebih adaptif dan fleksibel [8]. Tahapan pada proses penelitian terdiri dari 5 (lima) tahapan, yaitu : Perencanaan, Desain, Pengkodingan, Pengujian, dan ditutup dengan Rilis. Tahapan penelitian digambarkan pada Gambar 1 .

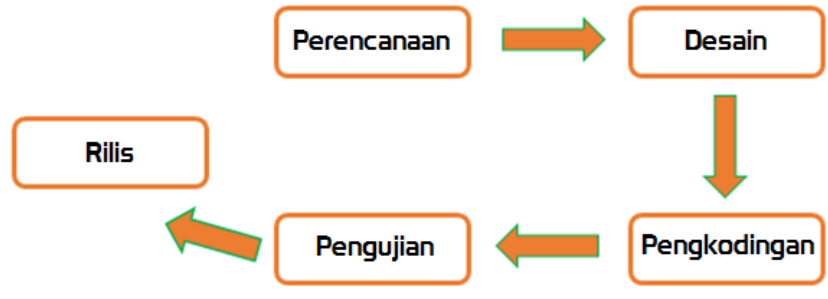

Gambar 1. Metode Perancangan

Pada setiap tahapan dilakukanlah berbagai proses dan akan menghasilkan berupa tujuan dari proses tersebut. Tabel 1 berikut menjelaskan proses dari setiap tahapan perancangan penelitian dan target hasil yang akan dicapai.

Tabel 1. Tahapan Metode Perancangan

\begin{tabular}{|c|c|c|}
\hline Tahap & Proses & Hasil \\
\hline $\begin{array}{c}\text { Tahap } \\
\text { Perencanaan }\end{array}$ & $\begin{array}{l}\text { Wawancara dan analisa pihak yang terlibat } \\
\text { pada sistem, serta identifikasi seluruh yang } \\
\text { berkaitan dengan system. }\end{array}$ & $\begin{array}{l}\text { Masukan terhadap sistem yang akan dibuat } \\
\text { dalam dokumen hasil perencanaan. }\end{array}$ \\
\hline $\begin{array}{l}\text { Tahap } \\
\text { Desain }\end{array}$ & $\begin{array}{l}\text { Memodelkan struktur objek dalam bentuk } \\
\text { diagram berdasarkan: interaksi antar aktor, } \\
\text { proses sistem, memodelkan kelas serta } \\
\text { relasinya. }\end{array}$ & $\begin{array}{l}\text { Dokumen hasil perancangan yang terdiri } \\
\text { dari : model interaksi actor, proses sistem, } \\
\text { memodelkan kelas serta relasinya. }\end{array}$ \\
\hline $\begin{array}{l}\text { Tahap } \\
\text { Pengkodingan }\end{array}$ & $\begin{array}{l}\text { Mengkoding sistem yang diawali dengan } \\
\text { database dan kemudian pengkodingan } \\
\text { program pada sistem. }\end{array}$ & $\begin{array}{l}\text { Aplikasi mobile penambahan fitur laporan } \\
\text { pengerjaan sholat dan hapalan Al-Qur'an. }\end{array}$ \\
\hline $\begin{array}{l}\text { Tahap } \\
\text { Pengujian }\end{array}$ & $\begin{array}{l}\text { Pengujian sistem dilakukan dengan Black } \\
\text { Box testing. }\end{array}$ & Dokumen hasil pengujian Black Box. \\
\hline $\begin{array}{l}\text { Tahap } \\
\text { Rilis }\end{array}$ & $\begin{array}{l}\text { Dilakukan pengujian oleh pengguna. Target } \\
\text { pengujian dilakukan pada salah satu SDIT. }\end{array}$ & $\begin{array}{l}\text { Dipublishnya aplikasi mobile dan dapat } \\
\text { digunakan pada SDIT. }\end{array}$ \\
\hline
\end{tabular}

\section{HASIL DAN PEMBAHASAN}

\subsection{Tahap Perencanaan}

Tahap ini dilakukan kegiatan menganalisa keadaan saat ini terhadap Sekolah Dasar Islam Terpadu pada proses pelaporan pengerjaan sholat dan menghapal Al-Qur'an para siswa melalui proses wawancara. Hasil wawancara tersebut, kesimpulan yang didapat yaitu bahwa media komunikasi yang dimanfaatkan oleh guru dan wali siswa pada proses laporan kegiatan sholat dan menghapal Al-Qur'an siswa berupa buku Tahsin, Tahfidz, Qur'an (TTQ) dan buku tersebut harus dibawa oleh siswa agar diisi oleh guru. Buku TTQ berisi laporan hafalan Al-Qur'an siswa mulai dari nama surah dan tingkat kelancaran hafalan, sedangkan buku pengerjaan sholat wajib siswa diparaf dan diisi oleh guru dan wali siswa.

Ketika melakukan pemantauan kemajuan hafalan Al-Qur'an serta laporan pengerjaan sholat, setiap hari kedua buku tersebut harus diisi oleh orang tua atau wali siswa. Namun untuk mengisi kedua buku tersebut orang tua atau wali siswa sering lupa untuk mengisinya. Pada kenyataan lain, siswa terkadang juga sering lupa untuk membawa kedua buku tersebut ke sekolah. Setelah dilakukan wawancara dengan pihak manajemen beberapa 
SDIT maka dapat disimpulkan bahwa Aplikasi Mobile Sebagai Media Komunikasi Dan Penyebaran Informasi Untuk Sekolah Dasar Berbasis Android yang sebelumnya telah dikembangkan akan sangat berguna di SDIT jika ditambah fitur laporan pengerjaan sholat dan hapalan Al-Qur'an.

\subsection{Tahapan Desain}

Tahap desain menggambarkan jalannya sistem yang disesuaikan melalui hasil yang ada dalam tahapan perencanaan dengan mendesain semua kebutuhan dalam sistem dalam bentuk diagram.

a. Desain Interaksi Aktor Pada Sistem

Interaksi dilakukan pengguna terhadap sistem digambarkan pada Gambar 2. Setiap usecase menunjukan kegiatan yang dapat dilakukan setiap aktor (guru dan wali siswa) pada sistem [9].

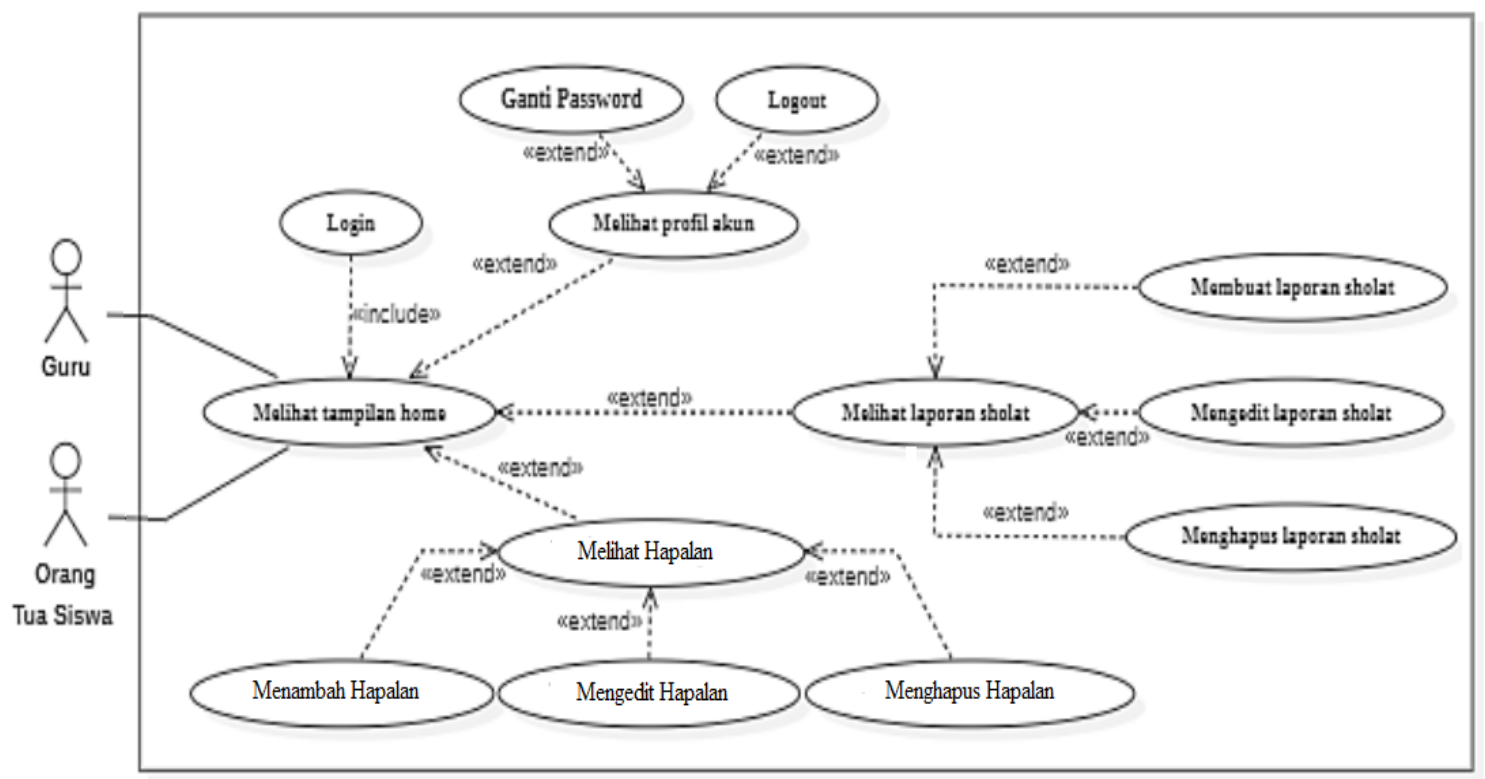

Gambar 2. Diagram Usecase Interaksi Aktor (Orang Tua Siswa dan Guru) pada Sistem

Setiap usecase pada Gambar 2 dideskripsikan pada Tabel 2 berikut.

Tabel 2. Deskripsi Diagram Usecase Interaksi Aktor (Orang Tua Siswa dan Guru) pada Sistem

\begin{tabular}{|c|c|c|}
\hline No & Usecase & Deskripsi \\
\hline 1 & Login User & Masuk ke dalam home page aplikasi. \\
\hline 2 & Logout User & Keluar dari page aplikasi jika telah selesai. \\
\hline 3 & Melihat tampilan home & Halaman awal setelah user melakukan login. \\
\hline 4 & Melihat profil akun & Melihat profil akun siswa (user) secara detail. \\
\hline 5 & Melihat laporan sholat & Melihat laporan pengerjaan sholat para siswa. \\
\hline 6 & Membuat laporan sholat & $\begin{array}{l}\text { Memilih dan memasukan laporan pengerjaan sholat serta } \\
\text { jadwal pelaksanaan. }\end{array}$ \\
\hline 7 & Mengedit laporan sholat & $\begin{array}{l}\text { Mengedit laporan kegiatan sholat jika terjadi kesalahan } \\
\text { memasukan data. }\end{array}$ \\
\hline 8 & $\begin{array}{l}\text { Menghapus laporan } \\
\text { sholat }\end{array}$ & $\begin{array}{l}\text { Menghapus laporan kegiatan sholat jika terjadi kesalahan } \\
\text { memasukan data. }\end{array}$ \\
\hline 9 & Melihat hapalan & Melihat hafalan surah Al-Qur'an siswa / anak. \\
\hline 10 & Menambah hapalan & $\begin{array}{l}\text { Memilih dan memasukan hafalan surah Al-Qur'an serta } \\
\text { tingkat kelancaran dan waktu hafalan. }\end{array}$ \\
\hline 11 & Mengedit hapalan & $\begin{array}{l}\text { Mengedit hafalan surah jika terjadi kesalahan memasukan } \\
\text { data. }\end{array}$ \\
\hline 12 & Menghapus hapalan & $\begin{array}{l}\text { Menghapus hafalan surah jika terjadi kesalahan memasukan } \\
\text { data. }\end{array}$ \\
\hline
\end{tabular}


b. Desain Interaksi Antar Kelas pada Sistem

Interaksi antar kelas yag ada pada sistem dideskripsikan pada Gambar 3.

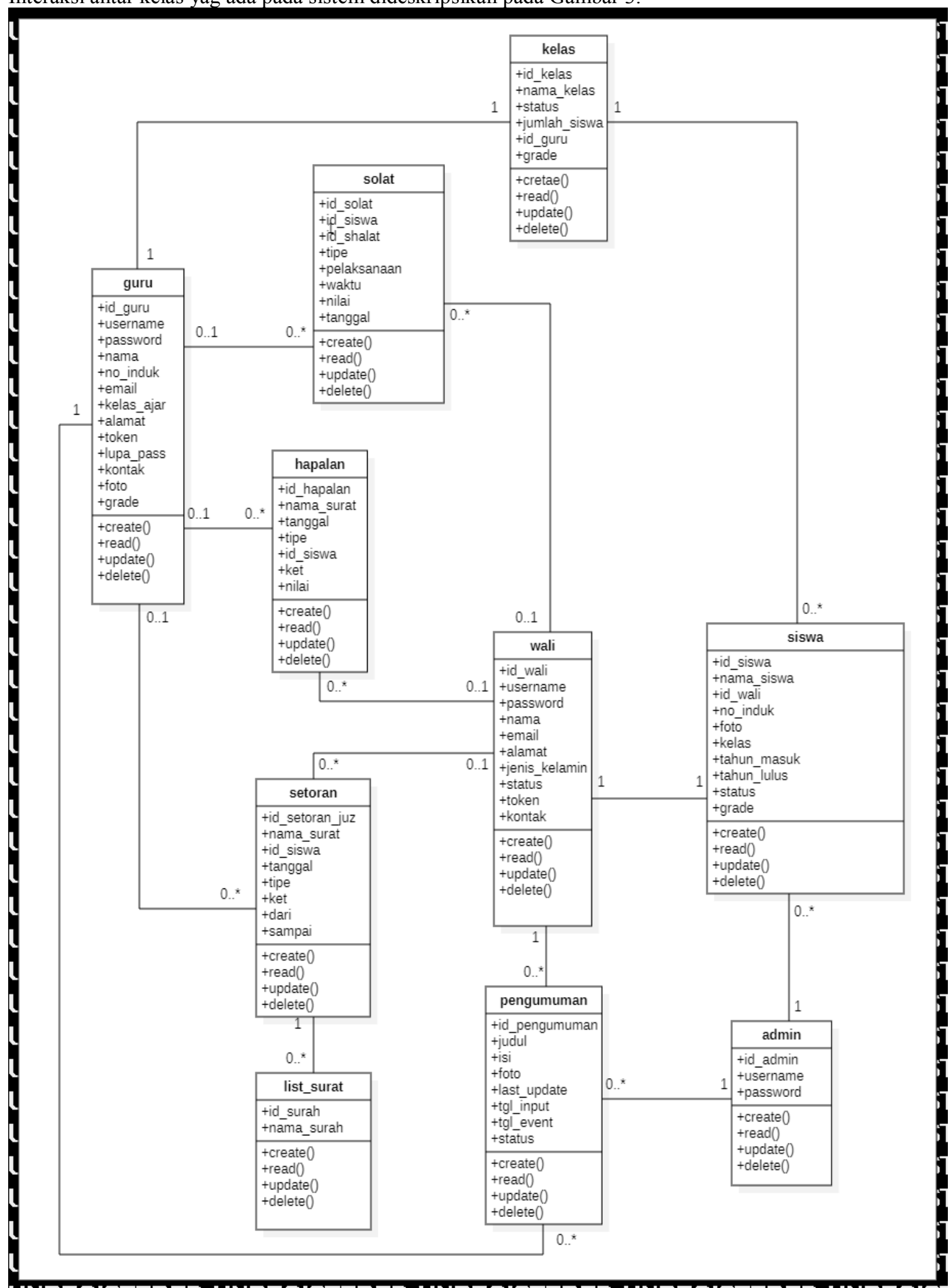

Gambar 3. Diagram Interaksi Antar Kelas Pada Sistem

Gambar 3 menggambarkan kelas berdasarkan hubungam, operasi, asosiasi dan atribut didalamnya. Gambar 3 juga menggambarkan tabel-tabel basis data yang dibutuhkan dan akan ditambahkan pada sistem aplikasi Mobile media komunikasi untuk sekolah dasar untuk penambahan fiture laporan pengerjaan sholat dan hapalan Al-Qur'an 
siswa. Sedangkan halaman yang dibutuhkan pada aplikasi untuk penambahan fitur dapat dilihat pada Tabel 3 dibawah ini.

Tabel 3. Halaman pada Aplikasi yang Ditambah dan Deskripsi Kegunaan

\begin{tabular}{|c|c|c|}
\hline No & Halaman Yang Ditambah & Deskripsi Kegunaan \\
\hline 1 & Home & $\begin{array}{l}\text { Memilihi jenis laporan yang akan dilihat/diinput, yaitu laporan } \\
\text { pengerjaan sholat atau hapalan Al-Qur'an. }\end{array}$ \\
\hline 2 & Form Sholat & $\begin{array}{l}\text { Melihat dan menginput laporan pengerjaan sholat melalui akun } \\
\text { orang tua siswa atau guru. User dapat menginput jenis sholat, } \\
\text { waktu sholat dan pelaksanaan sholat. }\end{array}$ \\
\hline 3 & Form Update Data Sholat & $\begin{array}{l}\text { Melakukan perbaikan jika terdapat kesalahan dalam mengisi } \\
\text { laporan kegiatan sholat siswa. }\end{array}$ \\
\hline 4 & List Hafalan & $\begin{array}{l}\text { Melihat dan memilih list surat sebelum menginput hafalan surat } \\
\text { siswa. }\end{array}$ \\
\hline 5 & Menu Hafalan & $\begin{array}{l}\text { Memilih memasukan setoran ayat atau murojaah sebelum masuk } \\
\text { ke halaman setoran ayat atau murojaah. }\end{array}$ \\
\hline 6 & Form Setoran Ayat & $\begin{array}{l}\text { Memasukan setoran ayat dan melihat hasil setoran siswa yang } \\
\text { telah dimasukan. User dapat menginput waktu setoran, } \\
\text { keterangan hafalan dan jumlah ayat. }\end{array}$ \\
\hline 7 & Edit Setoran Ayat & $\begin{array}{l}\text { Mengedit jika terjadi kesalahan memasukan data setoran ayat } \\
\text { yang dapat diedit atau dihapus. }\end{array}$ \\
\hline 8 & Form Murojaah Ayat & $\begin{array}{l}\text { memasukan setoran ayat secara berulang atau Murojaah. User } \\
\text { dapat menginput waktu setoran, keterangan (kurang lancar,lancar, } \\
\text { sangat lancar). }\end{array}$ \\
\hline 9 & Edit Murojaah Ayat & $\begin{array}{l}\text { Mengedit jika terjadi kesalahan memasukan data murojaah ayat } \\
\text { yang dapat diedit atau dihapus. }\end{array}$ \\
\hline
\end{tabular}

\subsection{Tahap Pengkodingan}

Tahap ini akan menghasilkan aplikasi Mobile laporan pengerjaan sholat dan hapalan Al-Qur'an. Tahap pengkodingan ini terbagi atas 2 macam proses yaitu proses pembuatan basis data serta proses pengkodingan pada system.

a. Pembuatan Basis Data

Aplikasi yang digunakan untuk pembuatan basis data adalah MySQL. MySQL merupakan Database Management System yang open source dan popular maka cocok untuk mendemontrasikan proses replikasi basis data [10]. Adapun tabel-tabel yang akan ditambah mengacu diagram kelas pada Gambar 3. Ada 4 (empat) tabel yang harus ditambahkan pada sistem yaitu : tabel_sholat, tabel_hapalan, tabel_setoran, dan tabel_list_surat. Berikut gambar struktur tabel yang dibuat.

\begin{tabular}{|c|c|c|c|c|c|c|c|c|}
\hline & $\#$ & Name & Type & Collation & Attributes & Null & Default Comments & Extra \\
\hline$\square$ & 1 & id_solat & $\operatorname{int}(11)$ & & & No & None & AUTO_INCREMENT \\
\hline$\square$ & 2 & id_siswa & varchan(100) & latin1_swedish_d & & No & None & \\
\hline$\square$ & 3 & id_shalat & varchar(100) & latin1_swedish_d & & No & None & \\
\hline$\square$ & 4 & tipe & varchan $(50)$ & latin1_swedish_di & & No & None & \\
\hline$\square$ & 5 & pelaksanaan & varchar(100) & latin1_swedish_d & & No & None & \\
\hline$\square$ & 6 & waktu & varchar(100) & latin1_swedish_d & & No & None & \\
\hline 0 & 7 & nilai & $\operatorname{int}(5)$ & & & No & None & \\
\hline$\square$ & 8 & tanggal & date & & & No & None & \\
\hline
\end{tabular}

Gambar 4. Struktur Tabel Sholat Pada Basis Data 
Pada Gambar 4 menunjukan terdapat 8 atribut tabel sholat yaitu : id_sholat (sebagi primary key), id_siswa, id_sholat, tipe, pelaksanaan, waktu, nilai, dan tanggal.

\begin{tabular}{|c|c|c|c|c|c|c|c|c|}
\hline & \# & Name & Type & Collation & Attributes & Null & Default Corments & Extra \\
\hline$\square$ & 1 & id_hapalan $?$ & int(11) & & & No & None & AUTO_INCREMENT \\
\hline$\square$ & 2 & nama_surat & varchan(20) & latin1_swedish_a & & No & None & \\
\hline$\square$ & 3 & tanggal & date & & & No & None & \\
\hline$\square$ & 4 & tipe & varchan(20) & latin1_swedish_ci & & No & None & \\
\hline$\square$ & 5 & id_siswa & $\operatorname{int}(11)$ & & & No & None & \\
\hline$\square$ & 6 & ket & varchan(20) & latin1_swedish_ci & & No & None & \\
\hline$\square$ & 7 & nilai & $\operatorname{int}(4)$ & & & No & None & \\
\hline
\end{tabular}

Gambar 5. Struktur Tabel Hapalan Pada Basis Data

Pada Gambar 5 menunjukan terdapat 7 atribut tabel hapalan yaitu : id_hapalan (sebagi primary key), nama_surat, tanggal, tipe, id_siswa, ket, dan nilai.

\begin{tabular}{|c|c|c|c|c|c|c|c|}
\hline & $\#$ & Name & Collation & Attributes & Null & Default Corments & Extra \\
\hline$\square$ & 1 & id_setoran $?$ & int(11) & & No & None & AUTO_INCREMENT \\
\hline$\square$ & 2 & nama_surat & varchar(100) latin1_swedish_ci & & No & None & \\
\hline$\square$ & 3 & id_siswa & $\operatorname{int}(100)$ & & No & None & \\
\hline$\square$ & 4 & tanggal & date & & No & None & \\
\hline$\square$ & 5 & tipe & varchar(100) latin1_svedish_d & & No & None & \\
\hline$\square$ & 6 & ket & varchar(100) latin1_svedish_ci & & No & None & \\
\hline$\square$ & 7 & dari & $\operatorname{int}(5)$ & & No & None & \\
\hline$\square$ & 8 & sampai & $\operatorname{int}(5)$ & & No & None & \\
\hline
\end{tabular}

Gambar 6. Struktur Tabel Setoran Pada Basis Data

Pada Gambar 6 menunjukan terdapat 8 atribut tabel setoran yaitu : id_setoran (sebagi primary key), nama_surat, id_siswa, tanggal, tipe, ket, dari, dan sampai.

\begin{tabular}{|llllll}
\hline$\#$ & Name & Type & Collation & Attributes & Null Default Corments Extra \\
\hline$\square$ & 1 & id_surat $P$ int(11) & No & None & AUTO_INCREMENT \\
$\square$ & 2 & nama_surat varchar(50) latin1_svedish_ci & No None
\end{tabular}

Gambar 7. Struktur Tabel List Surat Pada Basis Data

Pada Gambar 7 menunjukan terdapat 2 atribut tabel list surat yaitu : id_surat (sebagi primary key) dan nama_surat. 
b. Pengkodingan Aplikasi.

Pengkodingan aplikasi dengan dengan menggunakan perangkat lunak Ionic dan CodeIgniter sebagai framework PHP, sedangkan media editor sistem menggunakan Netbean IDE dan Visual Studio Code. Framework Ionic berbasis mobile merupakan kerangka kerja dari sebuah software yang bisa dijalankan di mobile operating system yang berbeda seperti Android, iOS dan Windows Phone [11]. PHP adalah skrip bersifat server-side yang ditambahkan ke dalam HTML [12]. Halaman yang dibuat sebanyak tertera pada Tabel 3 yaitu 9 (sembilan) tampilan halaman yang ditambahkan pada sistem aplikasi. Urutan tampilan halaman yang dibuat sesuai pada gambar tertera pada Tabel 4 .

Tabel 4. List Tampilan Halaman Sesuai Gambar

\begin{tabular}{clc}
\hline No & \multicolumn{1}{c}{ Tampilan } & Ditampilkan pada \\
\hline 1 & Halaman Home & Gambar 8 \\
2 & Halaman Form Sholat & Gambar 9 \\
3 & Halaman Form Update Data Sholat & Gambar 10 \\
4 & Halaman List Hafalan & Gambar 11 \\
5 & Halaman Menu Hafalan & Gambar 12 \\
6 & Halaman Form Setoran Ayat & Gambar 13 \\
7 & Halaman Edit Setoran Ayat & Gambar 14 \\
8 & Halaman Form Murojaah Ayat & Gambar 15 \\
9 & Halaman Edit Murojaah Ayat & Gambar 16 \\
\hline
\end{tabular}

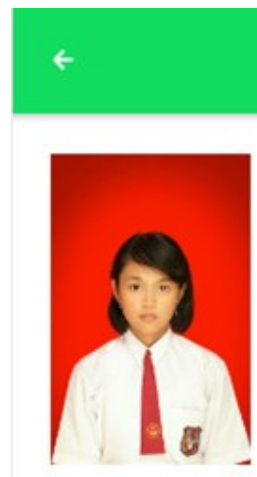

Home

\begin{tabular}{|c|c|}
\hline Nama : & salsabila \\
\hline NIS: & 1153 \\
\hline Kelas : & $4 A$ \\
\hline
\end{tabular}
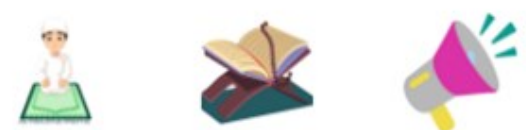

Sholat

Pengumuman

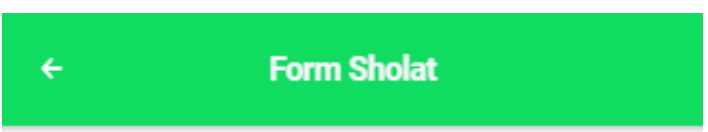

\section{Tanggal/Bulan/Tahun}

- Sholat

- Waktu Sholat

Sholat dilakukan secara

\section{INPUT SHOLAT}

\begin{tabular}{|c|c|c|c|c|}
\hline Tanggal & Sholat & nilai & Di isi & action \\
\hline $16-06-2020$ & zuhur & 75 & guru & $\square$ \\
\hline $11-06-2020$ & zuhur & 90 & guru & $\square$ \\
\hline
\end{tabular}

Gambar 9. Halaman Form Sholat 


\section{$\leftarrow \quad$ Form Update Data Sholat}

Tanggal/Bulan/Tahun

19-06-2020

Sholat

maghrib v

- Waktu Sholat pertengahan... v

- Sholat dilakukan secara sendirian v

\section{UPDATE DATA SHOLAT}

\section{HAPUS DATA SHOLAT}

Gambar 10. Halaman Update Data Sholat

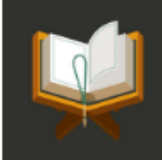

Setoran Ayat

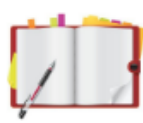

Murojaah Ayat

Gambar 12. Halaman Menu Hapalan

\begin{tabular}{|c|c|c|}
\hline$\leftarrow$ & List Hafalan & \\
\hline$\square$ & An-Nabaa' & $\rightarrow$ \\
\hline$\square$ & An-Nazi'aat & $\rightarrow$ \\
\hline$\square$ & ‘Abasaa & $\rightarrow$ \\
\hline$\square$ & At-Takwir & $\rightarrow$ \\
\hline$\square$ & An-Infithar & $\rightarrow$ \\
\hline 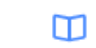 & Al-Muthaffifin & $\rightarrow$ \\
\hline
\end{tabular}

Gambar 11. Halaman List Hapalan

$\leftarrow$ Setoran Ayat An-Naas

Tanggal/Bulan/Tahun

* Keterangan

Dari Ayat

Sampai Ayat

\section{INPUT HAFALAN}

\begin{tabular}{|c|c|c|c|c|}
\hline Tanggal & ayat & Di isi & Keterangan & edit \\
\hline $\begin{array}{c}18-06- \\
2020\end{array}$ & $1-6$ & $\begin{array}{c}\text { wali } \\
\text { murid }\end{array}$ & Sangat Lancar & $\square$ \\
\hline $\begin{array}{c}11-06- \\
2020\end{array}$ & $1-5$ & guru & Sangat Lancar & $\square$ \\
\hline
\end{tabular}

Gambar 13. Halaman Form Setoran Ayat 
- Keterangan

Lancar $\mathbf{v}$

dari ayat

1

sampai ayat

6

\section{UPDATE DATA SETORAN}

\section{HAPUS DATA SETORAN}

\section{INPUT HAFALAN}

\begin{tabular}{|c|c|c|c|c|}
\hline \multicolumn{5}{|c|}{ INPUT HAFALAN } \\
\hline Tanggal & Nilai & Di isi & Keterangan & edit \\
\hline $\begin{array}{c}12-06= \\
2020\end{array}$ & 90 & $\begin{array}{l}\text { wali } \\
\text { murid }\end{array}$ & $\begin{array}{l}\text { Sangat } \\
\text { Lancar }\end{array}$ & $\square$ \\
\hline
\end{tabular}

Gambar 15. Halaman Form Murojaah Ayat

Gambar 14. Halaman Edit Setor Ayat

Nilai

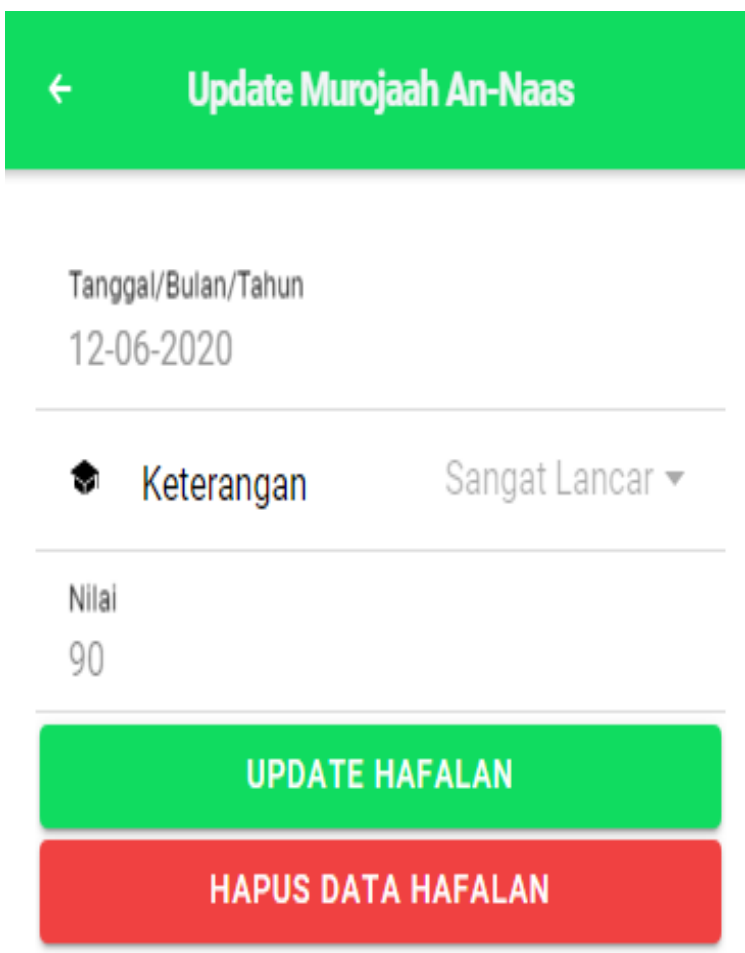

Gambar 16. Halaman Edit Murojaah Ayat 


\subsection{Tahap Pengujian}

Tahap pengujian sistem dilaksanakan melalui proses dengan metode pengujian Black Box. Keuntungan penggunaan metode Blackbox Tetsting adalah : (1) Penguji tidak perlu memiliki pengetahuan tentang bahasa pemrograman tertentu; (2) Pengujian dilakukan dari sudut pandang pengguna, ini membantu untuk mengungkapkan ambiguitas atau inkonsistensi dalam spesifikasi persyaratan; (3) Programmer dan tester keduanya saling bergantung satu sama lain [13][14]. Tabel 5 berikut menunjukan hasil pengujian fungsionalitas aplikasi.

Tabel 5. Hasil Pengujian Fungsionalitas Aplikasi

\begin{tabular}{clc}
\hline No & Fungsionalitas & Hasil Uji \\
\hline 1 & Membuat laporan pengerjaan sholat & Valid \\
2 & Mengedit laporan pengerjaan sholat & Valid \\
3 & Menghapus laporan pengerjaan sholat & Valid \\
4 & Membuat setoran ayat & Valid \\
5 & Mengedit setoran ayat & Valid \\
6 & Fungsionalitas menghapus setoran ayat & Valid \\
7 & Membuat murojaah ayat & Valid \\
8 & Mengedit murojaah ayat & Valid \\
9 & Menghapus murojaah ayat & Valid \\
\hline
\end{tabular}

Dari Tabel 5 diatas menjelaskan bahwa fitur aplikasi yang ditambahakan dan dikembangkan secara fungsionalitas telah berfungsi dan berhasil secara teknis. Dapat dipastikan pengujian setiap fungsionalitas dari aplikasi dilakukan berulang kali sehingga menghasilkan hasil uji yang valid. Ketika semua fungsionalitas aplikasi dipastikan berjalan dengan valid maka dilanjutkan ke tahap rilis.

\subsection{Tahap Rilis}

Pada tahap akhir, sistem yang telah diujikan dan dipastikan telah dapat digunakan maka dilakukanlah uji coba kepada calon pengguna. Pengujian pengguna dilakukan untuk mengevaluasi kelayakan dari sistem yang sudah dibuat telah sesuai dengan kebutuhan pengguna atau tidak. Setelah itu pengguna diharapkan memberikan pendapat mengenai apikasi yang dilakukan dengan menggunakan Google Form. Pertanyaan dan hasil pendapat yang terkumpul adalah sebagai berikut.

Pertanyaan :

1. Setujukah anda penambahan fitur laporan pengerjaan sholat dan hapalan Al-Qur'an siswa ini sangat membantu dalam membuat dan memberikan informasi mengenai pengerjaan sholat dan hapalan Al-Qur'an para siswa?

2. Setujukah anda penambahan fitur laporan pengerjaan sholat dan hapalan Al-Qur'an siswa telah sesuai dan efektif dengan kebutuhan para guru dan orang tua siswa?

3. Setujukah anda aplikasi fitur laporan pengerjaan sholat dan hapalan Al-Qur'an siswa mempunyai tampilan yang menarik, mudah digunakan, dan berjalan sesuai fungsinya?

Tabel 6. Hasil Pendapat Pengguna

\begin{tabular}{ccccc}
\hline Pertanyaan & $\begin{array}{c}\text { Sangat } \\
\text { Setuju }\end{array}$ & Setuju & $\begin{array}{c}\text { Kurang } \\
\text { Setuju }\end{array}$ & $\begin{array}{c}\text { Tidak } \\
\text { Setuju }\end{array}$ \\
\hline Ke-1 & $88,7 \%$ & $13,3 \%$ & $0 \%$ & $0 \%$ \\
Ke-2 & $83,3 \%$ & $16,7 \%$ & $0 \%$ & $0 \%$ \\
Ke-3 & $80 \%$ & $20 \%$ & $0 \%$ & $0 \%$ \\
\hline
\end{tabular}

Dari tabel 6 diatas menggambarkan jika aplikasi yang dikembangkan sangat membantu dan mudah untuk digunakan.

\section{KESIMPULAN}

Proses penelitian telah berhasil dilakukan sesuai dengan metode perancangan dengan tahapa yaitu : tahap perencanaan, tahap desain, tahap pengkodingan, tahap pengujian, dan tahap rilis, sehingga perancangan sesuai 
dengan tujuan penelitian. Tujuan penelitian ini adalah terciptanya suatu aplikasi sebagai media penyebaran informasi yang terdapat fitur laporan pengerjaan sholat dan hapalan Al-Qur'an siswa untuk SDIT yang dapat dioperasikan pada Mobile aplikasi sistem android dan bermanfaat bagi penggunanya, maka sistem tersebut telah tercipta dan telah terpublikasi yang dapat didownload pada play store dengan kata kunci "annafii". Hasil semua pengujian aplikasi yang menggunakan metode black box menunjukan hasil akhir dengan keterangan valid, sehingga dapat disimpulkan bahwa semua fungsi aplikasi telah berjalan dengan baik. Hasil kuisioner pendapat pengguna aplikasi menunjukan bahwa mereka semua setuju jika aplikasi yang diciptakan ini sangat membantu dan fiture yang ada sesuai untuk laporan pengerjaan sholat dan hapalan Al-qur'an siswa, dan aplikasi pun mudah untuk dipahami dan dijalankan.

\section{UCAPAN TERIMAKASIH}

Terima kasih disampaikan kepada yaitu :

1. Universitas Sriwijaya yang telah membiaya penelitian ini melalui Anggaran DIPA Badan Layanan Umum Universitas Sriwijaya tahun anggaran 2020 No. SP DIPA-023.17.2.677515/2020 Sesuai dengan SK Rektor Nomor : 0684/UN9/SK.BUK.KP/2020 Tanggal 15 Juli 2020.

2. $\quad$ Lembaga Penelitian dan Pengabdian kepada Masyarakat (LPPM) Universitas Sriwjaya

3. Pimpinan Fakultas Teknik Universitas Sriwijaya yang telah menyetujui gagasan penelitian ini.

4. Unit Penelitian, Pengabdian Kepada Masyarakat dan Kerjasama Fakultas Teknik Universitas Sriwijaya.

5. Pimpinan Jurusan Teknik Elektro Fakultas Teknik Universitas Sriwijaya

6. Rekan-rekan Dosen Jurusan Teknik Elektro Fakultas Teknik Universitas Sriwijaya

7. Rekan-rekan Mahasiswa Jurusan Teknik Elektro Fakultas Teknik Universitas Sriwijaya yang terlibat secara langsung dan tidak langsung pada penelitian ini.

8. Semua pihak yang terlibat pada penelitian ini.

\section{REFERENCES}

[1] D. W. SARI, A. H. DALIMUNTHE, and N. THEREZA, "Design of Mobile Application as Communication Media and Information Broadcasting for Elementary School Based on Android,” vol. 172, no. Siconian 2019, pp. 81-87, 2020, doi: 10.2991/aisr.k.200424.012.

[2] W. Van Casteren, "The Waterfall Model And The Agile Methodologies : A Comparison By Project CharacteristicsShort The Waterfall Model and Agile Methodologies," Acad. Competences Bachelor, no. February, pp. 10-13, 2017, doi: 10.13140/RG.2.2.36825.72805.

[3] G. Y. Pratama, "Implementasi Teknologi Hybrid Menggunakan Ionic Framework," STMIK AKAKOM Yogyakarta, 2017.

[4] Y. Purbandi, Trik Cepat Membangun Aplikasi Berbasis Web Dengan Framework CodeIgniter, 1st ed. Yogyakarta: Andi, 2016.

[5] A. H. Dalimunthe, "PERANCANGAN APLIKASI MOBILE PENYEBARAN INFORMASI BAGI MAHASISWA FAKULTAS TEKNIK UNSRI BERBASIS ANDROID,” pp. 430-437, 2018, [Online]. Available: http://avoer.ft.unsri.ac.id/documents/PROSIDING AVOER 10_FT UNSRI 2018.pdf.

[6] A. H. DALIMUNTHE, D. W. SARI, and P. KURNIASARI, "The Design of Online Promotion System for Entrepreneur in Palembang City Based on Mobile Application," vol. 172, no. Siconian 2019, pp. 73-80, 2020, doi: 10.2991/aisr.k.200424.011.

[7] R. Pressman, Rekayasa Perangkat Lunak Buku 1 Edisi 7, 7th ed. Yogyakarta, 2012.

[8] E. B. Pratama, "Pendekatan Metodologi Extreme Programming pada Aplikasi e-Commerce Berbasis M-Commerce Studi Kasus: Toko Buku An’Nur di Pontianak,” J. Khatulistiwa Inform., vol. V, no. 2, pp. 92-102, 2017, [Online]. Available: https://repository.bsi.ac.id/index.php/repo/viewitem/517.

[9] A. H. Dalimunthe, D. W. Sari, T. Elektro, U. Sriwijaya, A. Mobile, and P. Usaha, "Penambahan Fitur Voucher Digital Pada Aplikasi Mobile Media Promosi Elektronik Pelaku Usaha Di Kota Palembang,” pp. 445-452, 2020, [Online]. Available: http://ejournal.ft.unsri.ac.id/index.php/avoer/article/view/204/158.

[10] H. Yuliansyah, P. Studi, T. Informatika, and U. Ahmad, "Perancangan Replikasi Basis Data Mysql Dengan 
Mekanisme Pengamanan Menggunakan Ssl Encryption,” J. Inform. Ahmad Dahlan, vol. 8, no. 1, p. 102982, 2014, doi: 10.12928/jifo.v8i1.a2081.

[11] M. Suhaidi, N. Nurhadi, and L. Latip, "Penerapan Framework Ionic Dalam Perancangan Aplikasi E-Concept Sebagai Alat Terukur Dalam Perekrutan Simpatisan Pemilukada," Sebatik, vol. 24, no. 2, pp. 253-258, 2020, doi: 10.46984/sebatik.v24i2.1135.

[12] A. Firman, H. F. Wowor, X. Najoan, J. Teknik, E. Fakultas, and T. Unsrat, "Sistem Informasi Perpustakaan Online Berbasis Web," E-Journal Tek. Elektro Dan Komput., vol. 5, no. 2, pp. 29-36, 2016, [Online]. Available: https://ejournal.unsrat.ac.id/index.php/elekdankom/article/viewFile/11657/11249.

[13] P. Ammann and J. Offutt, Introduction to Software Testing. Cambridge University Press, 2016.

[14] T. S. Jaya, "Pengujian Aplikasi Dengan Metode Blackbox Testing Boundary Value Analysis (Studi Kasus: Kantor Digital Politeknik Negeri Lampung)," J. Inform. J. Pengemb. IT, vol. 3, no. 2, pp. 45-48, 2018, doi: 10.30591/jpit.v3i1.647. 